\title{
Assessing the Maturity of General Professional Competencies of Future Interpreters/ Translators: Problems and Solutions
}

\author{
Elena Porshneva - Indira Abdulmianova
}

\section{DOI: 10.18355/XL.2015.08.04.60-65}

\begin{abstract}
This paper has to methodize the problems that the teacher must pull through when he evaluates the skills of the future bachelor in Linguistics, more specifically future interpreter or translator. It is based on the experience of the teachers of the subdepartment of the French studies, interpreting and translating.

Nowadays the Russian academic community is looking for efficient methods of the evaluation of students' skills or competencies. As every fundamental change this process is very difficult and we would like to deal with our achievements in this domain to show the most important problems we were faced with and issues we found. Key words

competence-based approach, cognitive component of general professional competencies, cognitive-interpretative strategies
\end{abstract}

The current federal state higher education standard in the linguistic training area prescribes a competency-based training model that drastically changes the professional foreign language education, regarding both its content and performance assessment. The article discusses the problems teachers come across when trying to assess the maturity of general professional competencies (GPC) of future Bachelors of Linguistics - interpreters/translators, following FSES directives, through the example of GPC-3 competency which is formed and developed when studying the subject "Practical Course of the First Foreign Language".

The competency-based approach requires a focus not on assessing a trainee's level of language knowledge and skills, but on developing and assessing the level of maturity of competencies which include, apart from the knowledge component, cognitive, personal, value, cross-cultural and other components (Zimnyaya, 2004) The federal state standard, however, describes competencies in keeping with the same knowledge paradigm. For example, the general professional competency (GPC-3) is defined as "acquisition of a linguistic knowledge system comprising knowledge of basic phonetic, lexical, grammatical and word-building phenomena and functional regularities of a foreign language being learned and its functional varieties" (FGOS VO, 2014). In this case, trainees' cognitive activity of acquiring the above knowledge and skills is completely disregarded in the description of results.

In view of the new educational post-nonclassical paradigm providing for trainees to be actively involved in production and control of their knowledge, the cognitive component becomes the basic element of a competency. This component must undoubtedly be also taken into account when assessing the level of mastery of any competency, if FSES aims to implement the competency-based approach. Yet, the competency-based format for assessing training results proposed in the standard remains intrinsically traditional. What FSES suggests is describing the expected results by the items "knowledge, skills, mastery", i.e. in the knowledge paradigm format which means formal and pragmatic use of received ready-to-use knowledge without its personal apprehension. Inclusion of the cognitive component in the general professional competency structure allows the item "mastery" to be filled with cognitive content. It is sufficient to supplement it with characteristics of a controllable and independent cognitive activity of trainees, aimed at mastering general educational 
and special cognitive strategies, at building and acquiring one's own system of concepts in the language and culture being studied. (Koryakovtseva, 2012)

It should be noted that while the content of the knowledge component of general professional competency can be the same for the entire training area (teachers, interpreters/translators and cross-cultural professionals) and, in fact, is only dependent on the language being learned, the content of other components (activity, personal, value) and primarily the cognitive one are determined to some extent by trainees' future professional occupation.

Thus, when studying phonetic, grammatical or lexical material, a future foreign language teacher should learn to explain each language phenomenon. In language teaching, therefore, special attention should be given to shaping cognitive strategies of conceptualization, which provide students with the knowledge of how to reveal certain features, identify and classify facts, systematize and group language phenomena by theme and category; critically evaluate; detail and exemplify; reveal their language potential etc. (Schepilova. 2005)

When learning a language, a future interpreter/translator should develop cognitiveinterpretative strategies to be able to build a system of language tools according to semantic and functional features; systematize synonymous and antonymous language tools; select and keep in memory the most accurate correspondences in the mother tongue and a foreign language; compare language systems; interpret meanings of language tools in terms of the communicative task, situation and utterance listener. (Porshneva, 2015)

Intensification of cognitive strategies within the competency-based methodology is facilitated by the synergetic discursive approach to learning a foreign language as a self-developing communication system, a cultural phenomenon and simultaneously a natural process, which is described in detail in S.K. Gural's studies. (Gural, 2007)

It is important that, when starting to learn language phenomena, students consider any utterance as a unity of formal and semantic components, taking into account its stylistic and usual properties. Regularity or irregularity of forms is not a key criterion. Both in the process of observing language samples of native-speakers and in trainees' independent verbal creativity it is necessary to focus on revealing the semantic, emotional and pragmatic content of an utterance. No less important are trainees' reflexive activities and their ability to explain and define language phenomena being observed. Such metalinguistic cognitive activities of trainees help form personal meanings of learning and are indicative of trainees' speech meaningfulness level, motivation and independence. (Spiridonova, 2009)

How to assess the competency maturity level, considering the level of mastery of cognitive strategies? What demonstrated verbal actions can confirm competency maturity? How to formulate descriptors according to the competency-based approach and with regard to the future professional occupation?

Let us analyze the descriptor development process as exemplified by GPC-3. Under FSES HE GPC-3, the knowledge component of this competency implies the knowledge of a language system at phonetic, lexical and grammatical levels and of language functional varieties.

When assessing a competency, its maturity levels should be described. We define three levels - upper, medium and lower - which maximally approximate the existing traditional grading system. It should be remembered here that the competency-based approach implies that final grades "excellent", "good" or "satisfactory" should determine not so much a student's level of knowledge as the qualities which characterize the degree of maturity of the competency being evaluated. We will first try, under FSES directives, to identify characteristics of a formed competency, considering its cognitive component. During intermediate assessment on

61

XLinguae Journal, Volume 8 Issue 4, October 2015, ISSN 1337-8384 
the subject "Practical Course of the First Foreign Language" a student completing the second year of training must demonstrate:

Knowledge of phonetic and articulator features of sounds of the language being studied as well as the lexical, grammatical and syntactic minimum in the volume of the two-year training course.

Skills in forming his/her speech as per the norms of a standard foreign language with regard to the utterance listener, cross-cultural situation and communicative task (including the occupation-oriented one), retrieving and rewording the meaning and defining linguistic concepts.

Mastery of basic skills of intralingual interpretation/translation activities; basic elements of the foreign language professional learning strategy (building up linguistic knowledge and apprehending the functioning regularities of the mother tongue and a foreign language from the perspective of a future interpreter/translator).

To master this strategy, students should learn to apply their current knowledge and acquire new knowledge according to the communicative and/or occupation-oriented task at hand.

By the end of the initial training phase there could be the following maturity levels of this competency:

The upper level of mastering this competency is the ability to tackle occupationoriented, cross-cultural communicative tasks, using the knowledge, skills and qualities which students have developed and "taken possession of" due to their own efficient strategy for building up linguistic and communicative knowledge ("advance education"), with regard to the future professional occupation. In speaking and writing, the language tools used by students are fully consistent with the cross-cultural communicative situation and their choice is characterized by awareness and responsibility for any spoken or written utterance. When reading and listening, students should show the skills of adequate meaning interpretation. The employed language tools are indicative of how intralingual interpretation/translation skills (rewording the meaning) have been mastered.

The medium level of mastering this competency is the ability to tackle occupationoriented, cross-cultural communicative tasks, based on the reproduction of "ready-touse" memorized knowledge. In speaking and writing, the language tools used by students are generally consistent with the communicative situation, but, with correct grammar, there are semantic errors resulting either from a vaguely expressed meaning or from the focus on the "formal component". In reading and listening, students show no clear understanding or interpreting the meaning of a text or find it difficult to reword the meaning.

The lower level of mastering this competency is when students, while trying to tackle an occupation-oriented, cross-cultural communicative task, are unable to apply the appropriate cognitive strategies. In speaking and writing, the language tools used by students are not always consistent with the communicative situation and task, and there are a few speech errors which obscure understanding but do not preclude mutual understanding. In reading and listening, students show a misunderstanding of the text meaning, text reproduction rather than interpretation, weak verbal lability in rewording, and errors provoked by interference of the Russian language.

As is obvious, it is difficult to identify competency-based characteristics, remaining in the standard format. And this is what guidance documents require from university teachers. Can these characteristics be considered determining?

Another problem we would like to touch upon in this article is developing diagnostic material to measure the degree of maturity of a competency or a set thereof. The problem is primarily due to the fact that, despite the dynamic and functional description of language phenomena given in guidance manuals on modern cognitive 
linguistics, presentation of linguistic phenomena remains linear and one-dimensional. Building up linguistic knowledge, shaping acquisition strategies and diagnosing the proficiency level are possible through the use of discursive assignments within the synergetic approach. We are, therefore, devising special integrative test problem complex assignments helping identify the ability to mobilize knowledge, skills, qualities and cognitive strategies necessary for task solution. To provide a training exercise with cognitive content, it should be developed using authentic text material in the form of an occupation-oriented communicative or analytical (discursive) task. Thus we offer traditional written grammar tests as textual unities with blank spaces to be restored. Filling in the blanks when completing such an assignment requires the use of certain cognitive strategies and intralingual translation transformations: rephrasing, grammatical or lexical transformation, stylistic or pragmatic adaptation, explanation and definition.

In learning speech phonetics and proficiency control, use is made of imitation, analytical, search and mnemonic strategies. It is advisable to check the maturity level of a lexical competency using the exercises developed by I.R. Abdulmyanova to build an interpreter's/translator's professional bilingual thesaurus based on the cognitive communicative approach. These are, first of all, complex assignments aimed at invoking the personal cross-cultural thesaurus, conceptualizing knowledge, making alterations and filling in special charts and tables which reflect the skill of identifying semantic units in a text read or listened to. (Abdulmyanova, 2008)

The following situation strongly suggests a high maturity level of the competency under assessment: a student completes an assignment based on the discursive text analysis, i.e. he/she carefully examines the content, determines the meaning and hypothesizes before he/she proceeds to his/her test assignment by filling in the blanks with appropriate semantic units (grammatical, phonetic or lexical) and then explains and proves the appropriateness of his/her choice that is not inconsistent with the meaning of the restored text.

The focus on the differentiated assessment of competency maturity adds the training management function to the control process. Consideration of professionally relevant verbal actions, of which students have become aware, changes their focus in the training process, i.e. they become "focused on developing strategies of intralingual interpretation/translation activities and gaining professional skills rather than on memorizing and reproducing knowledge, i.e., ultimately, on passing exams". As soon as the development of lexico-grammatical skills becomes not the primary, but subordinate goal of mastering professionally relevant competencies, it evokes a natural inner need to work on the language and changes the quality of knowledge acquired by students.

Current control should involve regular discussions with students and joint assessment of the maturity and awareness degree of competencies that need to be mobilized to fulfill specific tasks, such as convey the essential idea of someone else's utterance; structure a text as per its purpose, genre and type; restore a text according to a grammatical norm; use clichéd means of an adequately communicative situation; and address an utterance to a particular person (adapt it with regard to how the representative of another culture perceives information).

Intermediate control should primarily aim to make students aware of text comprehension features, teach them to reveal the content of system and functional discourse properties, systematize language tools implementing the communicative situation of discourse, and identify time and spatial plans. Assignments should also include the identification of structural text units, text transformation (compression), text transfer to another register, and reproduction of a independently constructed text with allowance for its intonation format, communicative type, rhythmics and word 63

XLinguae Journal, Volume 8 Issue 4, October 2015, ISSN 1337-8384 
stress.

Since self-control requires the appropriately molded consciousness, it is advisable from the very start of training to use the potential of diagnostic, developing and educative functions control by focusing it on the development of self-consciousness, adequate self-evaluation and the sense of responsibility for educational activities. Adequate self-evaluation is provided by self-evaluation lists compiled in the first person. They suggest that students themselves, by answering positively or negatively, determine whether their skills meet the requirements for basic professional language proficiency. (Porshneva, 2004)

In addition, as intermediate control, we tested an achievement report form compiled by students in the form of free answers to key open questions. Students are encouraged, on their own, to analyze and evaluate their progress in the language by answering, also in the first person, the following questions as to their achievements over a month of work on the language:

What did I learn over this time?

What new did I learn?

How were my vocabulary, competence, text and interpretative skills enriched?

What did I learn to do in particular?

What verbal actions did I learn?

What is my foreign language learning strategy?

What difficulties did I encounter?

What are the points I'd like our group's (my) teacher to pay attention to at the next work phase?

When compiling the report, students learn to critically assess the enrichment of their linguistic and communicative experience, consciously regard their verbal actions and assess acquired knowledge and skills. The report encourages the comprehension of training efficiency and stirs up interest not so much in their evaluations as in mastering the material being studied.

This evaluation form is of critical importance in professional language learning, because in the final analysis it fosters self-development and self-improvement of trainees' linguistic identity. Such achievement reports perform the feedback functions for teachers, prompt further action and enhance the role of control in education process management.

Using the example of our attempt to settle the discrepancy between FSES Linguistics requirements and the competency-based approach, we have shown that, despite the obsolete wordings still found in FSES, linguistic education is undergoing dramatic change brought about by the new educational paradigm. The foreign language teacher cannot stay beyond these transformations which, as E.G. Tareva and N.D. Galskova underscore, are primarily characterized by "the growing problematicity, situatedness and "contextness' in education" and by the transition from "textual educational paradigm" to discursive. (Tareva, Galskova, 2013)

To meet in full the competency-based approach requirements, much attention should be given to invoking and developing the cognitive component of general professional competencies. The primary form of assessment of the competence maturity level should be complex textual assignments in the discursive task format. In order to stimulate students' cognitive activities, it is advisable to use self-evaluation lists and language learning progress reports which promote self-consciousness, adequate selfevaluation and the sense of responsibility for educational activities.

\section{Bibliographic references}


ABDULMYANOVA, I.R. 2008. Formirovanie dvuyazyichnogo spetsialnogo tezaurusa kak sostavlyayuschego komponenta yazyikovoy lichnosti perevodchika $\mathrm{v}$ ekonomicheskoy sfere (frantsuzskiy yazyik): Diss.na soisk.uchen.step.kand.ped.nauk: (13.00.02) / I. R. Abdulmyanova; GOU VPO "Nizhegorodskiy gosudarstvennyiy lingvisticheskiy universitet im. N.A.Dobrolyubova". - N. Novgorod

Federalnyiy gosudarstvennyiy obrazovatelnyiy standart vyisshego obrazovaniya (FGOS VO) po napravleniyu podgotovki 45.03.02 Lingvistika (uroven bakalavriata). Prikaz Minobrnauki Rossii ot 07.08.2014 N 940.

GURAL, S. K. 2007 Sinergetika i lingvosinergetika In Vestnik Tomskogo gosudarstvennogo universiteta $\mathrm{n}^{\circ}$ 302. pp. 7-10. ISSN 1561-803X.

KORYAKOVTSEVA, N. F. 2012 Sovremennaya metodika organizatsii samostoyatelnoy rabotyi izuchayuschih inostrannyiy yazyik Posobie dlya uchiteley Moscow: ARKTI ISBN 5-89415-244-5.

LABA, A. 2015. The use of comic strip conversations in shaping social behaviour of children with autism in the context of play. In: New Educational Review. Vol. 39, Issue 1, pp. 201-211. ISSN 17326729.

PESAKOVIC, D. - KOVACIC, D. - ABERSEK, B. - BILEK, M. 2015. Competence-based teaching for future education. In: New Educational Review. Vol. 39, Issue 1, pp. 216-239.ISSN 17326729.

PORSHNEVA, E. R. 2015. Ispolzovanie perevoda v protsesse yazyikovoy podgotovki buduschih perevodchikov In Vestnik Nizhegorodskogo gosudarstvennogo lingvisticheskogo universiteta im. N.A. Dobrolyubova. Vyipusk 29. - Nizhny Novgorod: FGBOU VPO «NGLU», pp. 136-150. ISSN 2072-3490.

PORSHNEVA, E.R. 2004. Mezhdistsiplinarnyie osnovyi bazovoy lingvisticheskoy podgotovki spetsialista-perevodchika: Avtoref.dis.na soisk.uchen.step.d-r ped.nauk: (13.00.08) / E. R. Porshneva; Nizhegorod.gos.lingv.un-t im.N.A.Dobrolyubova. N. Novgorod. Kazan.

SCHEPILOVA, A. V. 2005. Teoriya i metodika obucheniya frantsuzskomu yazyiku kak vtoromu inostrannomu: Ucheb.posobie dlya vuzov. Moscow: VLADOS. ISBN 5691-01423-4.

SPIRIDONOVA, O.V. 2009. Obuchenie studentov yazyikovogo VUZa artiklyu vo frantsuzskom yazyike: funktsionalno-paradigmaticheskiy podhod: Diss.na soisk.uch.step.kand.ped.nauk: (13.00.02) Nizhegorodskiy gos.lingv.un-t im.N.A.Dobrolyubova. N. Novgorod

TAREVA, E.G. - GALSKOVA, N.D. 2013. Innovatsii v obuchenii yazyiku i kulture: pro et contra. Moscow: IYASH: Nauchno-metodicheskiy zhurnal. 2013. $\mathrm{N}^{\circ} 10$. pp. 2 8. ISSN 0130-6073.

ZIMNYAYA, I.A. 2004 Klyuchevyie kompetentnosti kak rezultativno-tselevaya osnova kompetentnostnogo podhoda $\mathrm{v}$ obrazovanii. Moscow: Issledovatelskiy tsentr problem kachestva podgotovki spetsialistov.

Words: 2899

Characters: 21217

prof. Elena Porshneva

dr. Indira Abdulmianova

N.A. Dobrolyubov Nizhny Novgorod

State Linguistic University,

31a Minina street, Nizhny Novgorod

Russia 